Journal of Business Management and
Economic Research
2018, 2(11): 1 -15 DOI: $10.29226 /$ TR1001.2018.
Journal Homepage: https://www.jobmer.org

\title{
Innovation Capability Configuration in Complex Product Systems: The Brazilian Shipbuilding and Offshore Industry
}

\author{
Ariane Mello Silva Avila \\ Federal University of Rio Grande do Sul - arianemavila@gmail.com \\ André Cherubini Alves \\ Federal University of Rio Grande do Sul - andre.alves82@gmail.com \\ Paulo Antônio Zawislak \\ Federal University of Rio Grande do Sul - paulozawislak@ufrgs.br
}

\begin{abstract}
This paper aims to analyze how capabilities are developed and arranged to generate economic positive results in two complex product systems (CoPS) firms. In this context, this paper is a case study based on interviews with the Shipbuilding and Offshore Industry in Brazil covering the overall characteristics of the firm's capabilities. Results show that, out of the four innovation capabilities, there is a difference in the predominance and importance of them in each firm. The essence of this difference seems to be in the technological content of each firm which will require diverse capabilities' configuration. The results from these two CoPS firms, corroborate with the finding of previous studies that the success of any firm relies on the predominance of at least one of the four capabilities. As this study is conducted in Brazilian Shipbuilding and Offshore firms, this implies that the generalizability of this study's findings is limited to firms in Brazil and cannot be applied to other markets without a further validation. This empirical research has extended our understanding about the relation between innovation capabilities and CoPs. Also, the obtained findings offer the Brazilian executives and managers strategic insights in relation to need to develop innovation capacities even in complex productive structures. The academic value of this research is the analysis of CoPS through the perspective of innovation capabilities. Besides that, the analysis of a re-emergent industrial sector in a developing country context.
\end{abstract}

Keywords: Capabilities, Complex Product Systems, Technology, Business

\section{Introduction}

Industrial activity is often triggered or backed by governmental efforts and incentives to tackle contextual windows of opportunity to generate economic growth. This is often the case in Complex Product Systems (CoPS) (Davies and Brady, 1998). Scholars define CoPS as technological systems high in complexity and value (Miller et al., 1995; Hobday, 1998; Dedhayir et al., 2014). However, successful and lasting economic outcomes will depend on how firms develop their capabilities and become autonomous from any governmental dependency 
(Bergek et al., 2008; Hardstone, 2004; Hobday et al., 2005). This is only achieved if firms can find the right configuration of internal capabilities to tackle technology and business issues.

In order to achieve a long-term economic performance, firms must constantly orchestrate, develop and adapt their capabilities (Jacobides and Winter, 2005; Madhok, 1996; Loasby, 1998; Foss and Foss, 2004). Based on this, empirical evidence shows that innovation capabilities create different benefits for enterprises (Maldonado-Guzmán et al., 2018). Thus, considering the innovation capabilities, the innovation capability-based model to the firm developed by Zawislak, Tello-Gamara, Alves, Barbieux \& Reichert (2012, 2013), technology and business are two vectors that respectively correspond to four essential capabilities: development, operations, management and transaction capability.

Different research's has been conducted to analyze the influence of these four capabilities in individual industrial firms (Reichert et al., 2015; Alves et al., 2017; Zawislak, et al., 2018), the differences in the way capabilities are configured can be specially highlighted in CoPS where different firms combine diverse knowledge bases complementarities in order to produce the final outcome (Hobday, 1998; Davies and Hobday, 2005, Magnusson et al., 2005; Gholz, James and Speller, 2018).

The purpose of this paper is to analyze how these capabilities have been configured to allow the development of the industry in two firms belonging to the shipbuilding and offshore industry in Brazil. As in a CoPS, the industry is largely based on single or multi-projects. Companies engage in transient inter-firm arrangements that often require them to find new capability combinations to deal with new specifications or contextual situation of available suppliers. While some level of stability may provide during the process due to contractual safeguards, the continuity of the arrangement depends heavily on technical-economic performance of all participants and, consequently on key capabilities they are able to develop.

This paper is organized as follows. First, we discuss the literature on Capabilities and present the framework we'll rely on, distinguishing two major vectors: technology and business. Second, we present the research procedures of this study, followed by the discussion and conclusion.

\section{Addressing technology and business through firm's capabilities}

Innovation has been recognized as the greatest source of economic development. In this sense, to understand the phenomenon and help to improve companies' new knowledge proposition to the market, the literature has dealt with the topic using the innovation capability lens to explain the enterprises that innovate (Lall, 1992; Bell and Pavitt, 1995; Chandler, 1992). Based on that, Primo and DuBois (2012, p.48) claim that "as economic activity shifts away from developed economies towards emerging markets, the ability of firms in these markets to stand on their own as global competitors is of paramount importance".

The concept of capabilities was first presented by Richardson (1972) defining them as the 'knowledge, experience and skills' of the firm. To Dosi, Nelson and Winter (2000) capabilities express the firm's "know-how" about doing certain things which means "to have a generally reliable capacity to bring that thing about as a result of intended action" (p.2). Routines are the capabilities' "building-blocks" (Grant, 1991; Chandler, 1992; Collis, 1994; Dosi, Nelson and Winter, 2000; Peng et al., 2007; Alves et al., 2011). Moreover, since capabilities carry the intrinsic nature of each firm based on knowledge, they explain why firms are different (Nelson, 1991).

Not only knowledge possessed by firms is different, but it is constantly subjected to a change through a cumulative process of learning. Sustainable competitive advantage is regarded to be the result of how firm's ability to deal with this process through dynamic capabilities (Teece et 
al., 1997; Eisenhardt and Martin, 2000). Even though different concepts are found in literature, we understand that in order to create and sustain competitive advantage over time, firms must constantly develop and create new and dynamic capabilities. These dynamic capabilities, as a matter that involves knowledge and practice resources, it is directly related to generate innovations as outcomes.

However, while much discussion has been realized on the role played by capabilities and dynamic capabilities, it is often the hard to define what the important capabilities are (Alves et al., 2011). Zawislak et al. (2012) propose a framework of innovation capabilities that are define four capabilities that can be found in any firm: technology development capability, operations capability, management capability and transaction capability. These capabilities are dived into a technological and a business driver.

Figure 1. Analytical framework

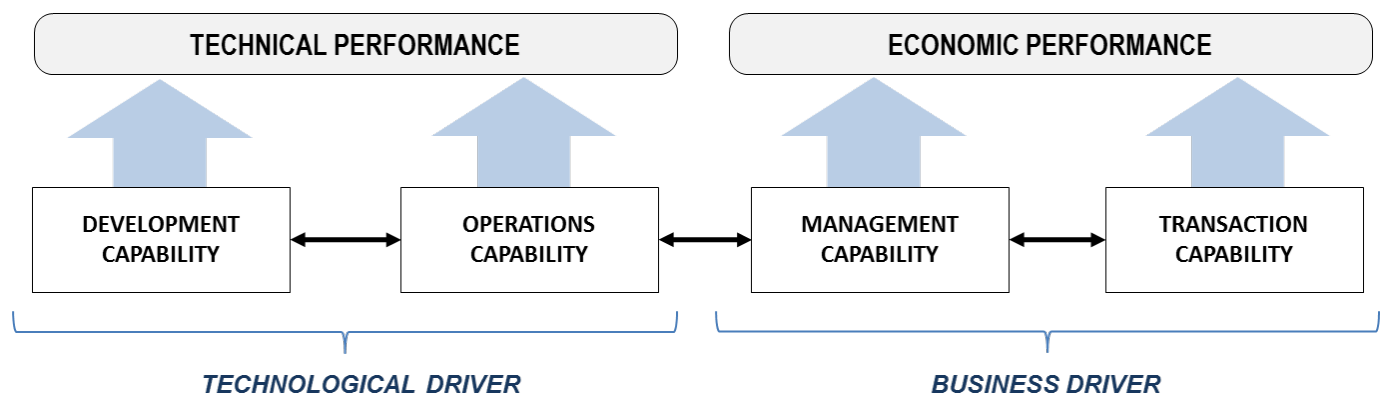

(Adapted from Zawislak et al., 2013)

These technological and business drivers both mix two important functions of the firm, that of an agent of change and entrepreneurial activity and, at the same time, of an agent of coordination of internal resources that has to fulfill external gap in the market in an efficient manner.

The Technological Driver

Development and Operations Capabilities correspond to the technological driver of the firm. Zawislak et al. (2012) defined development capabilities as the "The ability that any firm has to interpret the current state of the art, absorb and eventually transform a given technology to create or change its operations capacity and any other capability aiming at reaching higher levels of technical-economic efficiency" (p17).

Operations capability is the "ability to perform the given productive capacity through the collection of daily routines that are embedded in knowledge, skills and technical systems at a given time" (Zawislak et al. 2012, p.17). For Wu et al. (2010), operational capabilities are firmspecific sets of skills, processes, and routines, developed within the operations management system, that are regularly used in solving its problems through configuring its operational resources.

These two capabilities combined involve what Lall (1992) described as the way firms absorb, process, create, change and generate feasible technical applications and the knowledge-based products and services. Or what Bell and Pavitt (1995) defined as the resources needed to generate and manage technological change.

The technological driver represents the Schumpeterian function of creating an operation, changing the efficiency patterns of an industry. However, while these capabilities are important, they are only valuable if they can generate positive economic outcomes, that is, 
business. Therefore, development and operations capabilities are insufficient in explaining positive performance. They must be complemented by management and transaction capabilities.

The Business Driver

Moreover, the management capability is related to the development of a wide range of skills to deal with unpredictable circumstances. According to Whitley (1989) management capability not only reduces the costs imposed by uncertainty, but also is dynamic and evolutionary. It concerns the maintenance of the different areas of the firm and requires the constant improvement of resource's coordination and use, thus mixing continuity and innovation strategically.

The transaction capability is defined as the combination of activities that the firm uses in order to minimize transaction costs (Zawislak and Gamarra, 2013), thus, complementing the technological capability. Furthermore, for Gamarra (2013), transactional capability is defined as a repertoire of skills, processes, experiences, knowledge and routines that the firm uses to minimize their transaction costs.

The business driver combines the functions proposed by Coase (1937) and Penrose (1959), on the one hand, the make or buy decision arises from the comparison of the costs of organizing certain transactions internally within the boundaries of the firm in relation to carrying the same transactions in the market. On the other, it highlights the ability of management to efficiently allocate internal resources efficiently and expand the boundaries of the firm.

These two major drivers outline that, in order to exist and perpetuate itself overtime must, the firm must be capable of combining these four capabilities in order to complete the full cycle of bringing any technical solution (goods and services) to fill an economic transaction in the most efficient manner.

\section{Complex product systems}

Complex Products Systems (CoPS) are sometimes considered cases of exemption for some theories where mass production behavior and a regular technological trajectory can be expected (Peltoniemi, 2011). CoPS are high-value capital-goods produced by request, not a mass production, which requires a high degree of specialization and are usually produced by projects. Due to the high level of investment such, projects are sometimes backed by government intervention (Hobday, 1998), through subsidies, market protection or and incentives.

For "complex" it is understood the breadth of knowledge and skills required to reflect other critical product dimensions (Hobday, 1998). The concept of Complex Product Systems is related to levels of uncertainty and risk (Hofer and Halman, 2004). According to Hansen and Rush (1998), the high investment in engineering and technology for the generation products with large numbers of components adapted is the risk which the firm runs by developing project with large specifications. Thus, examples of CoPS include aerospace industry, military systems, offshore oil platforms and others.

Different than in mass markets where the technology of production reflects specific market behavior, in such systems industrial arrangement are usually fragmented among many firms which are specialized in the production of parts or modules that will be integrated in the final product to be delivered to one or few clients. Firms rely on different sets of skill and technology as well as contractual arrangements and consequently must find different capabilities configuration to deal with the stage of production they are responsible for. In this sense, 
analyzing this type of industry can allow reflections on how the different set of skills and technology influences the capability configuration of each firm in the arrangement.

\section{Research design and method}

The aim of this research is to analyze the influence played by the two major vectors of capabilities, technology and business in an emerging industry. In order to accomplish this aim, we conducted an exploratory study where evidences of two empirical analyses were collected. We collected data from two companies of the Shipbuilding and Offshore Industry in Brazil. The two companies represent two major processes in the shipbuilding supply chain. Firm A is responsible for the final module's integration, whereas Firm B is responsible for building the platform hull.

According to the National Union of Construction and Repair Offshore Marine Industry (SINAVAL), South Korea and China are the leading world oil producers with $67 \%$. All other countries together represent $15 \%$ of the total production amount, including United States (military ships), Singapore (offshore platforms), India and Brazil.

The Brazilian Offshore Industry started in the 50's going through times of growth and crisis. From the beginning of the current decade, because of the large growth exploration and offshore oil production in the country, the Shipbuilding industry of Brazil began a recovery process. There are 47 shipyards in Brazil all over the country, concentrating most in the southeast, specifically in the state of Rio de Janeiro. Furthermore, there are 11 new shipyards in construction. The Brazilian Offshore Industry is a typical case of an industry ruled by government policies. This is because the national government, through us, is the only national company interested in this industry.

Figure 2. Example of technological Interfaces involved in one Platform Construction Project

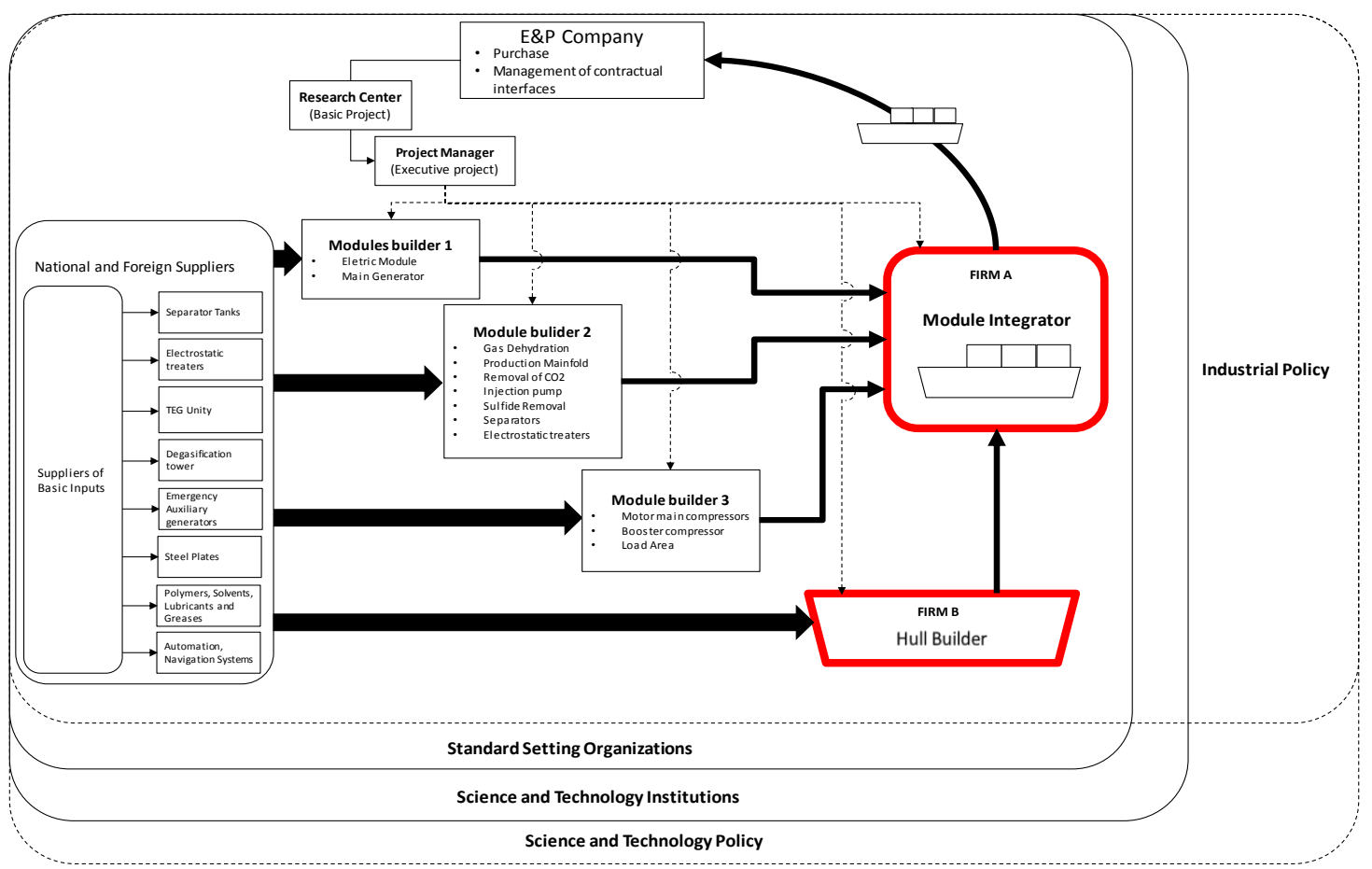




\section{Companies interviewed}

Two of the main shipyards are located in the southernmost part of the country and operate the shipyards under a public concession. The industry has been operating in the region 8 year from now. Rio Grande's Offshore Pole (as it is called) has already built two platforms so far and there are two more scheduled for conclusion by the end of the year.

The two empirical analyses were taken at the two main firms operating in Rio Grande's Offshore Pole. We present here the most important data related to each of these firms in order to characterize them and to promote a better understanding about the findings of this research.

The first firm contacted was Firm A. The firm was founded in 2005 by the merge of three other firms (each one acting in a different industry), one from building industry, the second from heavy engineering, and the third which operated in the oil and gas industry. The first operation Firm A performed was the construction of Floating, Production, Storage and Offloading (FPSO) platform required by public auction by the major oil and gas explorer and producer in the country (E\&P company). Nowadays, Firm A is also participating in the assembly a semisubmersible platform and has recently delivered the second FPSO. The responsibility of this firm in the platform development projects are related to the engineering, buying main components, building and assembling the platform, as well as testing them. They have around 3,000 employees.

The other firm studied in this paper was Firm B which was created in 2010 and hired by the E\&P company through public auction for building eight bottom hulls for offshore platforms extraction in deep waters. The main components produced by Firm B are hulls, modules and drillships. Figure 2 shows a general example of the distribution of activities of this CoPS industry and the supply chain position of the two companies analyzed.

\section{Data collection and analysis}

The data collection was performed as threefold. First, we collected information from secondary sources (public information, internet, firm's websites and open documents, annual reports, and so on). As a second stage we performed in-depth interviews with the head office manager of Firm A and the production engineer of Firm B. In Appendix A we present the research protocol undertaken on both interviews. The interviews occurred in 2012 and 2013 in the city of Rio Grande, Rio Grande do Sul (RS), south of Brazil at the headquarters of the firms.

\section{Results}

According to the literature review on capability theories and specially regarding the analytical framework proposed (Zawislak, et al., 2012), we'll further explore the collected data. We will firstly analyze each firm as separate in its specificities and then we discuss their relationship and common understandings.

\section{FIRM A - Module Integrator}

The main activities developed by Firm A concerns assembling the modules that compose the offshore platforms. There is a difference between regular shipyards and the work Firm A does, especially because it doesn't produce the platform's hull. Although the other analyzed firm is a shipyard that produces the platform's hull and assembling activity, these two firms are also competitors, concerning the assembling process. Any shipyard can essentially be eligible for making the assembly process. And this is because that E\&P company usually opens two public auctions, one to produce the roofs and the other for the assembling activity. 
When the interview was taken, Firm A was working on two simultaneous projects of offshore platforms. These projects may take around 2 to 3 years to be completed. The average cost of a platform produced in Brazil is around 1.5 billion dollars. In order to deliver an offshore platform project, Firm A must develop and organize different capabilities.

The first capability is related to technological development. In relation to this capability, it is a requirement of the public auction from Oil E\&P Firm, that $65 \%$ of the material used to produce the platforms must be made in national territory. As the coordinator of construction and assembling said: "In a general sense, the work Firm A does is analogous as a Lego play, you have to assemble all the pieces to form the set of pieces that an offshore platform is". So, their main problems do not come from the technological basis but are in finding national suppliers that have the required specialization.

The technological development is not new, that is, Firm A follows strict requirements and specifications for building and assembling offshore platforms used worldwide. The interviewee says that their innovation is just geographical since it is being produced in Brazil now, especially in the south region. Thus, the suppliers are also getting specialized to enter in this industry. But concerning the product - the platform itself - it has no innovation.

However, there are two technological innovations highlighted by the interviewee, that are a special kind of a moving ceiling to protect workers from wind and rain during their activities and an electronic equipment to measure workers' real ability to weld. This equipment was created due to a need of the firm to test and know what the real abilities of their workers were. They explained that ever since the firm started to operate in the region, there were lots of people willing to work with them, but they did not have the real ability to operate and weld. This equipment is now being licensed by Firm A. As we can see, these two main technological innovations are not directly related to the final product or to high-technology development, but mainly operations capabilities concerning to the basic need for both infra-structure and training to guarantee production and economic efficiency.

The second required capability concerns operations. This is the area that Firm A defines as its obligation, that is, to make it work. They organized their production process by projects, and inside each project they have to assure total quality. The deadlines must be respected and the general rules of international offshore industries, like safety and security are strictly followed as well. However, what stands out from this analysis is that, all these operational issues from quality to deadlines requires an intense attention from management in order to ensure that specifications are met.

Management capability, it therefore the most important capability of firm A. There are several aspects to be highlighted related to management capabilities. First, since the firm is organized mainly by projects thus each project is independent and has its team, areas and self-business units. Firm A has only two general director and manager that respond for all the projects. Other important information is related to the constitution of the firm, that only when it was approved by the public bid, that it formally established its formal and physical structure. That is to say that it was all planned and specified only for this complex special product: offshore platforms.

As the coordinator of construction and assembling says: "The main competitive advantage is the engagement and commitment that we do our job with in order to produce the exact product that was asked for". For that reason, they count with a special kind of co-participation, that is, there is a technical team representing the E\&P Company in all the stages of production organized by Firm A. They are in constant exchange, collaborating and co-participating during the whole production process. 
One of the major problems and struggles that concern Firm A success is related to individual competencies development. There is a lack of specialization and skills in the different job positions according to what the offshore industry requires. Thus, the major challenge is in developing and forming specialized qualified labor force, especially at a technic level. Nowadays, among $81 \%$ of Firm A's workers are from the south of Brazil.

As this is an only customer firm and it is hired before the start of the projects by public auction, the main concern of transactional capabilities was with suppliers: selection, contracts, costs, specificities, and so on. At this regard, the interviewee said that they use to buy from national industries the raw material and material with less complex transformation, and from abroad the complex materials and technology related. The second major challenge of this firm is related to the search and relationship to be developed with potential suppliers. It is difficult to find quality and specialized suppliers nationally, so the interviewee said that they have to develop close relationship with potential and already operating suppliers. This relationship demands that Firm A get involved with suppliers from instructions on specifications to direct training and close supervision. The transactional challenge, as the same case of the human resources, takes time, because it demands the mobilization of people, learning, abilities and, the most important, it requires the development of new capabilities.

\section{FIRM B - Hull Builder}

The main activity developed by Firm B is to produces the platform's hull, unlike firm A, which assemble the modules that compose the offshore platforms. Firm B was created by and engineering company to compete in the Brazilian E\&P Company's bids for construction of ship hulls for oil extraction. When the interview was taken, Firm B was working with the construction of seven ship hulls. This service is carried out by reproduction, that is, for instance, all the ship hulls must follow the same technical design. The main competitive advantage of the company according to the interviewee is the manpower (technical resources, thus called individual competencies).

The employees' knowledge comes mostly from the remaining companies of the 80 's (first development of the Brazilian Shipbuilding industry). The coordinator of maintenance engineer said: "the company sought for new employees in the old industries back from the $80 \mathrm{~s}$ ". But as this decision was not enough to meet the needs of the firm, they developed training centers to overcome the training needs of the employees.

The domestic shipbuilding offers direct competitors in the firm level, however, this is not seen as a threat, since management considers its resources able to compete in this market. Moreover, the demand for this type of activity is large, which distributes the service offering. The company believes that there is no innovation in activities; as follows a pattern established by the contracting company.

In order to building platforms, firm B must develop and organize different capabilities. Development capability, although it does not produce any breakthrough, it leads the firm to be up to date with state of the art in the sector. Automation has been one of the main efforts of the firm in its operations and it represents a change in on the firm's technological base. As an example of automation, Firm B has weld inspection with ultrasound and robotic painting. Other important advance was related to the use 3D software for design and plans the architecture of the vessels to be produced. In this case, managers will have access to all materials use in the construction of the platform through a 3D model that shows each component individually.

Technological development and qualification are at the highest priorities to this firm. It has capitalized in university-industry relations by investing the and technological center within the 
universities technological park for developing new solutions as well as preparing human resources to work in the sector.

The second capability is operation. Firm B has a tonnage of steel processing capacity of 11 thousand per month. This is the area that Firm A defines as its greater differentials. According to director of engineering the operations capability is the main company's ability, because they are in constant upgrade. They control their production process by tracking chips, where it is possible to locate all equipment and materials for the construction of platforms within the yard of the firm. Although, CoPS industries never obtain scale as in mass manufacturing industries, by winning the governmental-bid for producing eight equal hulls, the firm can have economies of repetition. This will allow improvement in routines and techniques which will eventually lead to efficiency.

The third capability is management. Firm B has a matrix organizational structure. Thirty percent of the company was bought by a Japanese firm in order to add and improve technical knowledge and technology to operations. Firm B has five thousand employees at various levels. Most of the staff is professional level (like welders and electricians), and part of them have higher education degree completed (such as engineers, managers and accountants).

Transactional capability was considered the least influential capacity in the Firm B. In the construction of platforms, FIRM B has only one customer, the E\&P company. On the supplier side, the firm does not have much autonomy for searching for alternatives. Contractual clauses for the company are tied to registered suppliers and local industry. One of the major problems is the dependence of suppliers, but this is a condition prescribed in the bidding.

\section{Discussion}

Despite being in the same industry and part of the same value chain, they are two different companies with different capabilities arrangement. The basis of the difference in capabilities lies in the technological content domain by each company. If we see a product as the result of technology of a firm (Baecker, 2006), in a complex value chain such as the Shipbuilding and offshore industry, the ultimate expression of technological content that we have in any company is how much each contributes to the final product.

The final product for Firm A, is final platform. However, firm A does not build it from scratch. The basic project usually is delivered to Firm A who has only to follow the steps described in the manual in a "Lego-like" type of assembly. While the company has some operational capabilities to build some modules, the main activity for the company is to integrate the final models on the platform. Since time and quality are the main drivers for the company, its managerial capabilities are key in order to ensure the optimal allocation of resources. The company works by projects and so it needs to be able to hire technical and human resources effectively and contractual arrangements with suppliers and labor are extremely relevant. This justifies that the company does not have a team of engineers engaging full-time in developing technology of its own. The technological stage of Firm A is to ensure that the full integration of modules work properly. Therefore, it only needs to know what the resources are, where to find them and where to place them. No wonder it is a company run by administrators because they deal with complex project management. From the EPC acronym (Engineering, Procurement and Construction), the letter P seems to be its flagship. Any technical development happens with focus in problem solving to improve operations.

In the case of Firm B, final products include platforms, drill ships and tankers. The company has managed to dominate other steps of the construction process. The activities that are carried out in the companies' dry dock go beyond "just fit" parts. It dominates the technology for steel 
processing, cutting and welding which turns out to be important for Firm B to invest in technology to improve techniques and materials. In addition to knowing what the necessary resources are and managing production deadlines, it must also improve technology. This explains the investments in partnerships with the local universities in order to conduct research and develop technology. Because of the high level of investment, and higher complexity, the firm $B$ needs to ensure also a higher level of stability and long-term plans with labor also being hired for longer term. In this sense, because of its complexity and investment, firm B is less likely to be dissolved. Moreover, because its technological content is more specific than Firm A, and Firm A is relatively less complex, Firm B, has the potential of building an entire vessel from scratch.

While Firm A, can enjoy short term business opportunities because of its ability to quickly pull the necessary resources, the lack of specificity of Firm A, is also a potential weakness in the long run. As the more technological intense Firm B broadens its technological boundaries it might become economically advantageous to vertically integrate similar activities of Firm A and compete for same markets. What seems to be a key advantage for Firm A is its flexibility, nonetheless, in this case, flexibility brings also high volatility.

In order to endure, it seems that firms should plan a shift from a business-driven approach to a more technological-driven one. By analyzing the cases, it seems reasonable to affirm that firm $\mathrm{B}$, due to investments made in technology and its concerned with improving capabilities and technology beyond the operational level, will lead to further reaching business opportunities. Firm B shows clearly the concerned of management with expanding its knowledge boundaries.

The innovation capability configuration shows the arrows where the firm is stronger at the wider the arrows (Figure 3). Firm A clearly focus its attention in operations and dealing with several suppliers. In order to integrate these needs it must have a stronger management capability. Because the activities of Firm A are less specific, Firm A has more flexibility to enter or exit the arrangement. Conversely, Firm B has invested in more specific technology and it masters more stages of the productive activity and could eventually build the whole vessel by itself if it incorporates the activities of Firm A once they are less specific and volatile.

Figure 3. Capabilities predominance in each interviewed firm

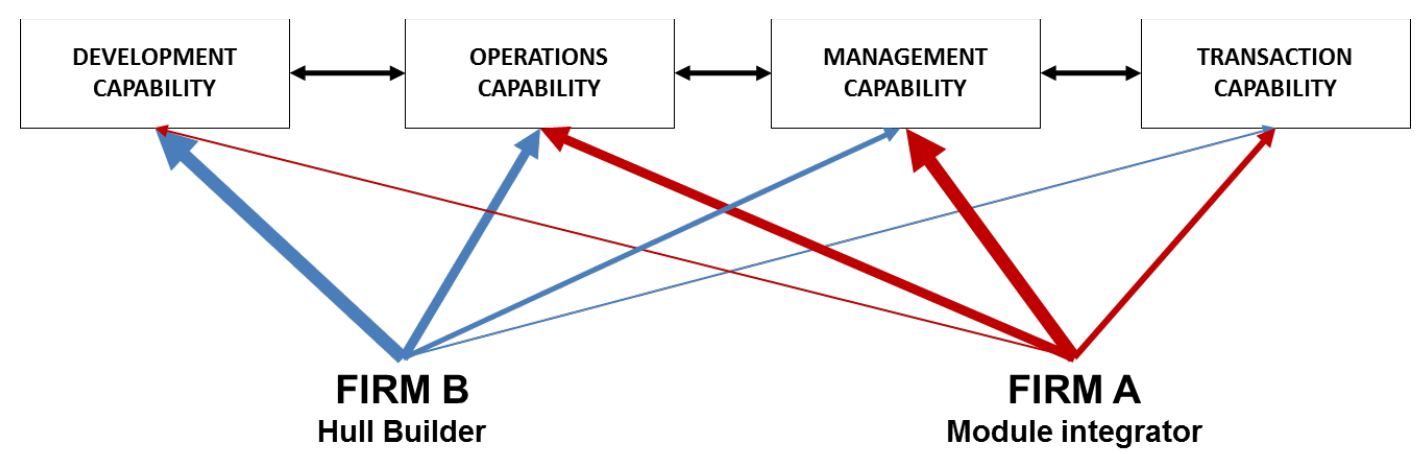

Because Firm B has invested more intensively in technology, it is expected that this firm will have more chances to continue, opening new windows of opportunity that will not be available to Firm A. In this sense, Firm A is more of a temporary arrangement that to exploit a business opportunity, whether Firm B, is probably looking for the future. 
We could attempt to draw a proposition that, those who invest in technology increase the lifetime of the firm. However, this is not a risk-free decision. It involves the knowledge on technological and market. The Brazilian Shipbuilding and Offshore industry is being backed by the government and the State-owned Oil E\&P firm who claim a 20 year perspective of oil exploration. Much uncertainty remains to what will happen to the industry after this singleclient market is over. Firms willing to compete in international markets will have to catch-up with world-class technology and start develop new solutions and this is a tough challenge which might request other types of governmental intervention and incentives.

\section{Conclusion}

The purpose of this research was to analyze the influences of the capabilities of the firm to address technology and business issues. This was done in the context of the Shipbuilding and Offshore industry in Brazil. We aimed at contributing to a literature gap that relates the development of capabilities in a Complex Products and Systems emerging industry.

As in a CoPS (Miller et al., 1995; Hobday, 1998; Dedhayir et al., 2014), the Shipbuilding and Offshore industry in Brazil is largely based on single or multi-projects. In other words, this industry is interpreted as a complex of industrial activities that are linked over a long period to planning and for the assembly of a final product of high added value.

Originally based in Zawislak et al. (2012) analytical framework, two empirical analyses were performed to find how these firms organized their capabilities, because they are part of an emerging industry in Brazil. The empirical contributions of this research are not only to set the analyze the major vector and configuration status, but also to present a picture of this emerging industry which faces many challenges in order to turn to a future and become capable of focusing on technological development.

Considering both firms, the final product for Firm A, is final platform. In the case of Firm B, final products include platforms, drill ships and tankers. Based on that, the firm A has the capacity of management and the capacity of operation like predominant innovation capacities. However, firm B has the capacity for development and the ability to operate as predominant.

In general, both companies have a focus on production activity, which evidences the need to control productivity indices and low production costs. However, while firm A seeks management as an alternative to control these actions, firm B has the capacity to develop the mechanism to create alternative solutions.

Finally, we highlight the limits of this study. It was held at a single moment through interviews. Besides the lack of generalizability capacity, it would be best to analyze this process in different periods of time to see the shifts or changes in capability configurations. Future research is highly encouraged, especially on CoPS industry by mapping the differences in capability configuration across all firms belonging to the arrangement.

\section{Acknowledgements}

This study is part of a research project called "Technological Interfaces of the of the Brazilian Shipbuilding and Offshore Industry" with the financial support of the Brazilian Government research funding agency called Brazilian National Council for Scientific and Technological Development (CNPq). 


\section{References}

Alves, A, C., Zen, A, C., Padula, A. D. (2011), "Routines, Capabilities and Innovation in the Brazilian Wine Industry", Journal of Technology Management and Innovation 6 (2), 128-144.

Alves, A.C.; Barbieux, D.; Reichert, F.; Tello-Gamarra, J.; Zawislak, P.A. (2017), “Innovation and dynamic capabilities of the firm: defining and assessment model", Revista de Administração de Empresas, v. 57, p. 232-244.

Baecker, D. (2006), “The Form of the Firm”, Organization. 13(1), p.109-142.

Bell, M., Pavitt, K. (1993), “The development of technological capabilities". In: Trade, technology and international competitiveness. 1st ed. World Bank, Washington, DC.

Bergek, A., Tell, F., Berggren, C., Watson, J., (2008), “Technological capabilities and late shakeouts: industrial dynamics in the advanced gas turbine industry, 1987-2002", Industrial and Corporate Change 17 (2) 335-392.

Chandler, A. (1992), "Organizational capabilities and the economic history of the industrial enterprise", Journal of Economic Perspectives. 6 (3), 79-100.

Coase, R. (1937), "The nature of the firm", Economica, v. 4, n. 16, p. 386-405, 1937

Collis, D.J. (1994), "Research note: how valuable are organizational capabilities?", Strategic Management Journal.15 (8), 143-152.

Davies, A. Brady, T. (1998), “Policies for a Complex Product System”, Futures, Vol. 30, No. 4, pp. 293-304.

Davies, A., Hobday, M. (2005), “The Business of Projects Managing Innovation in Complex Products and Systems", Cambridge University Press.

Dedhayir, O.; Nokelainen, T.; Makinen, S.K. (2014), “Disruptive innovations in complex product systems industries: a case study", Journal of Engineering and Technology Management, 33, 174-192.

Dosi, G., Nelson, R., Winter, S. (2000), "Introduction: The Nature and Dynamics of Organizational Capabilities". In: Dosi, G., Nelson, R., Winter, S. (Eds.). The Nature and Dynamics of Organizational Capabilities. Oxford University Press, New York.

Eisenhardt, K., Martin J. (2000), “Dynamic capabilities: What are they?", Strategic Management Journal 21 (10/11), 1105-1121.

Foss, K.; Foss, N. (2004), “The next step in the evolution of RBV: Integration with Transaction Cost Economics", Management Review. 15 (1), 107-121.

Gamarra, J. E. T. (2013), “A natureza tecnológico-transacional e o desempenho da firma”, Tese (Doutorado em Administração) - Programa de Pós-Graduação em Administração, Universidade Federal do Rio Grande do Sul, Porto Alegre.

Gholz, E.; James, A.D.; Speller, T.H. (2018), “The second face of systems integration: An empirical analysis of supply chains to complex product systems", Research Policy 47, 1478-1494.

Grant, R., (1991), “The resource-based theory of competitive advance: implications for strategic formulation", California Management Review 33 (3), 114-135.

Hansen, K.L., Rush, H. (1998), "Hotspots in complex product systems: emerging issues in innovation management", Technovation. 18 (8/9), 555-561. 
Hardstone, G.A.P. (2004), “Capabilities, structures and strategies re-examined: incumbent firms and the emergence of complex product systems (CoPS) in mature industries", Technology Analysis Strategic Management. 16 (2) 173-196.

Hobday, M. (1998), "Product Complexity, innovation and industrial organization”, Research Policy, 26, pp.689-710.

Hobday, M., Davies, A., Prencipe, A. (2005), "Systems integration: a core capability of the modern corporation", Industrial and Corporate Change. 14 (6) 1109-1143.

Hofer, A.P., Halman, J.I.M. (2004), “Complex products and systems: Potential from using layout platforms", Artificial Intelligence for Engineering Design, Analysis and Manufacturing, 18, 5569.

Jacobides, M.; Winter, S. (2005), "The co-evolution of capabilities and transaction costs: Explaining institutional structure of production", Strategic Management Journal. 26, 395413.

Lall, S. (1992), "Technological capabilities and industrialization", World Development, v. 20, n. 2, p. 165-186.

Loasby, B. (1998), "The organization of capabilities", Journal of Economic Behavior and Organization. 35, 139-160.

Madhok, A. (1996), "The organization of economic activity: Transaction Costs, Firm Capabilities, and the Nature of Governance", Organization Science. 7 (5), 577-590.

Maldonado-Guzmán, G.; Garza-Reyes, J.A.; Pinzón-Castro, S.Y.; Kumar, V. (2018), "Innovation capabilities and performance: are they truly linked in SMEs?", International Journal of Innovation Science.

Magnusson, T., Tell, F., Watson, J. (2005), "From CoPS to mass production? Capabilities and innovation in power generation equipment manufacturing", Industrial and Corporate Change. V.14, (1), pp. 1-26.

Miller, R., Hobday, M., Leroux-Demers, T., Olleros, X. (1995), “Innovation in complex system industries: the case of flight simulators", Industrial and Corporate Change 4, 363-400.

Nelson, R. R. (1991), “Why do firms differ, and how does it matter?", Strategic Management Journal, Winter Special Issue, 12, pp. 61-74.

Peltoniemi, M. (2011), "Reviewing Industry Life-Cycle Theory: Avenues for Future Research", International Journal of Management Reviews. 13, 349-375.

Penrose, E. (1959), "The theory of the growth of the firm", Oxford University Press, New York. 272 p. Reprinted in 1995.

Peng, D. X., Schroeder, R. G., Shah, R. (2007), “Linking routines to operations capabilities: A new perspective", Journal of Operations Management 26, (6), 730-748.

Primo, M.A.M.; DuBois, F. (2012), “Technological Capabilities of Brazilian Shipbuilding Suppliers". Journal of Technology Management \& Innovation. v.7, 2.

Reichert, F. M., Camboim, G. F., \& Zawislak, P. A. (2015), “Capacidades e trajetórias de inovação de empresas brasileiras", Revista de Administração Mackenzie (Mackenzie Management Review), 16(5).

Richardson, G. (1972), “The organization of industry”, Economic Journal 82 (327), 883-896. 
Teece, D., Pisano, G., Shuen, A. (1997), "Dynamic capabilities and strategic management", Strategic Management Journal 18 (7), 509-533.

Whitley, R. (1989), “On the nature of managerial tasks and skills: their distinguishing characteristics and organization", Journal of Managerial Studies, 26, 209-224.

Wu, S., Melnyk, S., Flyn, B. (2010), “Operational capabilities: The secret ingredient", Decision Sciences 41 (4), 721-754.

Zawislak, P.; Alves, A.; Tello-Gamarra, J.; Barbieux, D.; Reichert, F. (2012), “Innovation Capability: Technology development to Transaction Capability". Journal of Technology Management and Innovation. 7 (2), 14-27.

Zawislak, P.; Tello-Gamarra, J. (2013), “Transactional Capability: Innovation's missing link", Journal of Economics, Finance and Administrative Science. 18 (34), 2-8.

Zawislak, P. A.; Tello-Gamarra, J.; Fracasso, E. M. (2018), “Technological intensity and innovation capability in industrial firms", Innovation \& Management Review, p. INMR-042018-012.

[1] State-owned mixed economy company - Brazilian Energy, Oil and Gas Industry

[2] Portion located underground beneath a salt layer below the seafloor 


\section{Appendix a}

\section{Protocol questions:}

1. A brief history of the firm:

2. Where the firm's knowledge came from?

3. How many employees?

4. How does the firm develop the knowledge and techniques to do what it does?

5. Does the firm have competitors? National or international level:

6. How is the knowledge of the firm in relation to these potential competitors?

7. How could you describe the commercial activities of the firm?

8. How is the relationship of the firm with customers and suppliers? Selling and buying?

9. What are the main requirements the firm does to its suppliers?

10. What are your main activities and projects now?

11. How does prices and coasts are defined in public auctions?

12. How long it takes to conclude a project?

13. How does the knowledge transfer process work with the firms involved in the process?

14. How could you describe the managerial activities of the firm?

15. How could you describe the financial and budget management activities of the firm?

16. How could you describe the past 6 years' changes the firm passed through?

17. How could you describe the organizational structure of the firm?

18. Could you give an innovation example?

19. How could you describe the main competitive advantage of the firm?

20. Could you describe how you understand the firm according to the 4 capabilities framework? 